Supplementary Information

\title{
Direct Cytosolic Delivery of Proteins Through Co-Engineering of Proteins and Polymeric Delivery Vehicles
}

Yi-Wei Lee, David C. Luther, Ritabrita Goswami, Taewon Jeon, Vincent Clark, James Elia, Sanjana Gopalakrishnan and Vincent M. Rotello*

*E-mail: rotello@chem.umass.edu

Table of contents

1. Materials 1

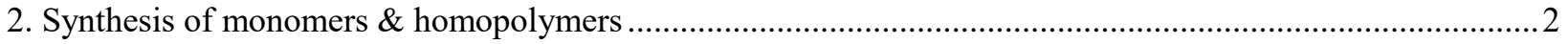

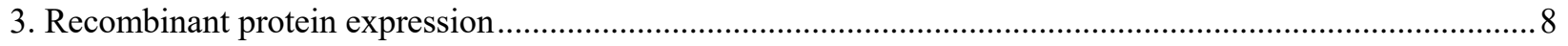

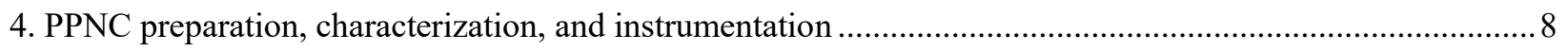

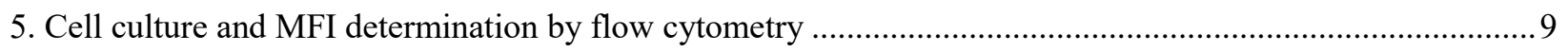

6. Cytosolic delivery evaluation by flow imaging cytometry .........................................................................

7. Mammalian cell viability assay for PONI polymers ............................................................................

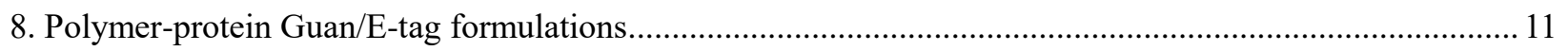

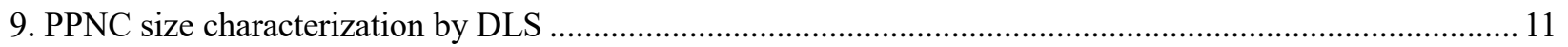

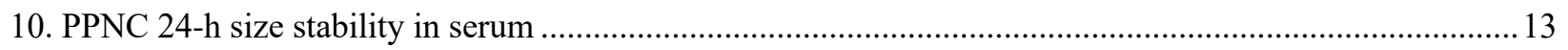

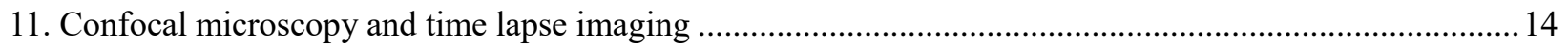

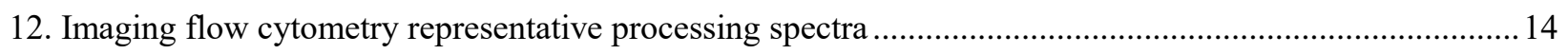

13. Uptake mechanism evaluation through endocytic inhibition................................................................. 16

14. Cytosolic delivery evaluation with different length of E-tag GFPs .......................................................... 17

15. Confocal Large Imaging of HEK-293T LoxP-dsRed-STOP-LoxP-EGFP Reporter Delivery..................... 17

16. Zeta Potential of PPNC GFPE20 Complexes at Varying Guan/Etag Ratios............................................... 19

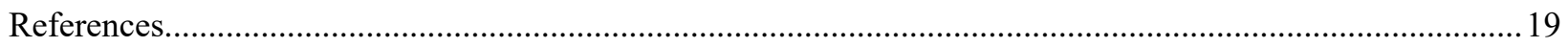

\section{Materials}

All chemicals and solvents for syntheses were purchased from Fisher Scientific and Sigma-Aldrich, and used without further purification, unless otherwise stated. The chemicals were used as received. Dichloromethane (DCM) and tetrahydrofuran (THF) used as a solvent for chemical synthesis and dried per standard procedures. All reagents/materials were purchased from Fisher Scientific and used as received. NIH-HEK-293T cells (ATCC CRL-3216) were purchased from ATCC. Dulbecco's Modified Eagle's Medium (DMEM) (DMEM; ATCC 30-2002) and fetal bovine serum (Fisher Scientific, SH3007103) were used in cell culture. The yields of the compounds reported here refer to the yields of spectroscopically pure compounds after purification. 1H NMR spectra were recorded at $400 \mathrm{MHz}$ on a Bruker AVANCE 400. 


\section{Synthesis of monomers \& homopolymers}

Materials and Instrumentation. 3-(dimethylamino)-1-propylamine, 1,3-propanesultone, 2,2,2-

trifluotoethanol (TFE), di-tert-butyl dicarbonate, and $2^{\text {nd }}$ generation Grubbs' catalyst were purchased from Sigma-Aldrich and used as received. Furan, and 3-Bromopropylamine hydrobromide were obtained from Alfa Aesar and used as received. Melaimide, ethyl vinyl ether (EVE), and N,N'-Di-Boc-1H-pyrazole-1carboxamidine were purchased from Acros Organics and used without further purification. Ethyl acetate, acetonitrile, hexane, diethyl ether anhydrous, methanol, tetrahydrofuran, dichloromethane, triethylamine, dimethylformamide, sodium bicarbonate, sodium sulfate, maleic anhydride, and trifluoroacetic acid were purchased from Fisher Scientific and used as received. $3^{\text {rd }}$ generation Grubbs' catalyst (G3) (dichloro-di (3- bromopyridino)-N,N'-dimethylenoimidazolino- $\mathrm{Ru}=\mathrm{CHPh}$ ) was synthesized according to a previously published procedure. ${ }^{11} \mathrm{H}$ NMR and ${ }^{13} \mathrm{C}$ NMR spectra were recorded on a Bruker 400/500 spectrometer (Bruker, Madison, WI) in appropriate deuterated solvents.

\section{Synthesis of monomers}

2.1 Synthesis of compound 1.

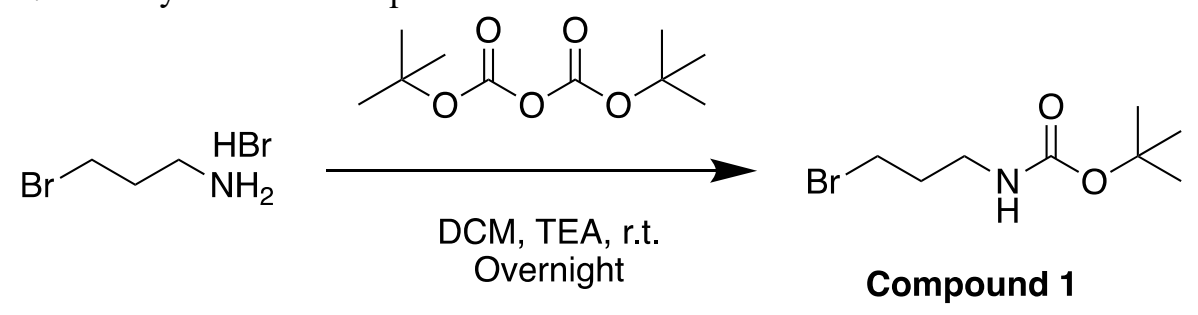

To a $500 \mathrm{ml}$ round bottom flask equipped with a stir-bar was added $150 \mathrm{ml}$ of dichloromethane (DCM). Next,3-Bromopropylamine hydrobromide (36.49 g, $166.7 \mathrm{mmol}, 1.0$ e.q.) was added to the DCM solution. Then, triethylamine $\left(\mathrm{Et}_{3} \mathrm{~N}\right)(93.1 \mathrm{ml}, 667 \mathrm{mmol}, 4.0$ e.q.) was added to the reaction mixture. Finally Di-tert-butyl dicarbonate ( $46 \mathrm{ml}, 200 \mathrm{mmol}, 1.2$ e.q.) was added dropwise. After addition of ditert-butyl dicarbonate, the reaction was stirred overnight at room temperature (r.t.). Afterwards, the DCM was rotovaped, diluted with $100 \mathrm{ml}$ of diethyl ether, and extracted with $1 \mathrm{M} \mathrm{HCL}(1 \mathrm{x} 20 \mathrm{ml})$, saturated sodium bicarbonate $(2 \times 20 \mathrm{ml})$, and brine $(1 \times 20 \mathrm{ml})$. The organic layer was dried with sodium sulfate, filtered, and rotovaped to yield compound 1 as a clear liquid. Compound 1 was purified using column chromatography and silica gel as the stationary phase, with using ethyl acetate:hexane $(1: 4, \mathrm{v} / \mathrm{v})$ as mobile phase. Chemical yield: $60 \%$, colorless crystals. ${ }^{1} \mathrm{H} \mathrm{NMR}\left(400 \mathrm{MHz}, \mathrm{CDCl}_{3}\right): \delta 4.68(\mathrm{br}, 1 \mathrm{H}), 3.44(\mathrm{t}, 2 \mathrm{H})$, $3.28(\mathrm{~m}, 2 \mathrm{H}), 2.04(\mathrm{~m}, 2 \mathrm{H}), 1.44(\mathrm{~m}, 9 \mathrm{H})$. 


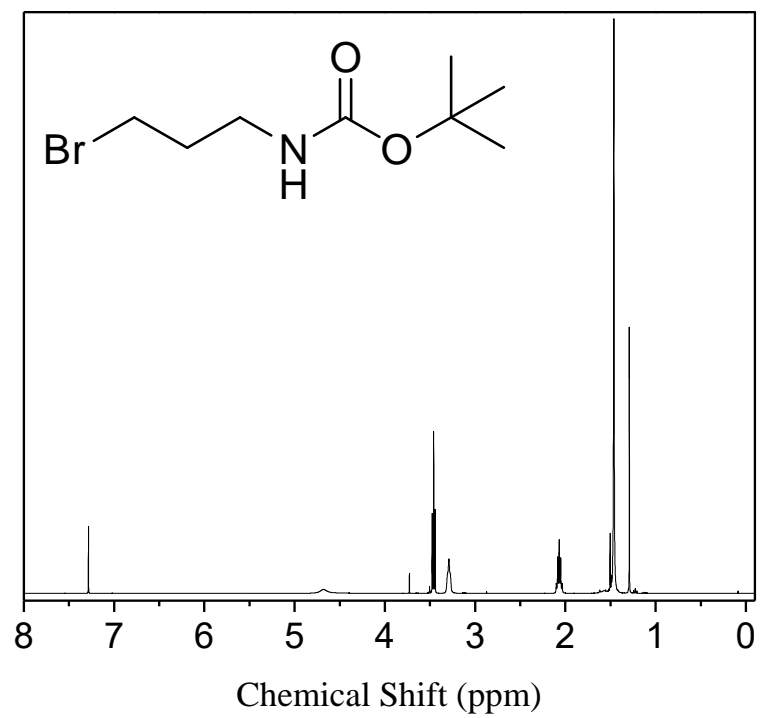

Figure S1. ${ }^{1} \mathrm{H}$ NMR spectra of compound 1 in $\mathrm{CDCl}_{3}$.

$2.2 \quad$ Synthesis of Compound 2.

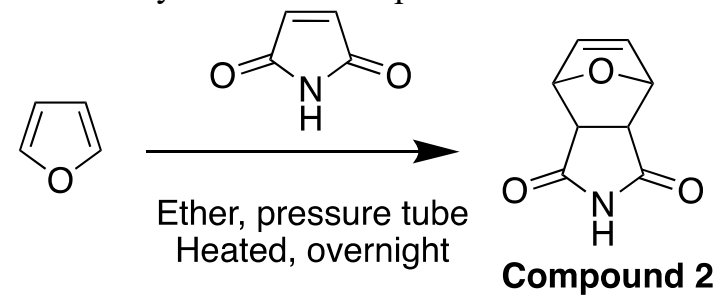

In a pressure tube, furan $(9 \mathrm{ml}, 123.4 \mathrm{mmol}, 1.5$ e.q. $)$ and maleimide $(8.0 \mathrm{~g}, 82.2 \mathrm{mmol}, 1.0$ e.q. $)$ were added in addition to $50 \mathrm{ml}$ of diethyl ether. The tube was sealed and heated at $100{ }^{\circ} \mathrm{C}$ overnight. Afterwards, the pressure tube was cooled to r.t. and the formed solid was removed, filtered, and washed with copious amounts of diethyl ether to isolate compound 2 as a white solid and was used without further purification. Chemical yield: $82 \%$, white powder. ${ }^{1} \mathrm{H}$ NMR $\left(500 \mathrm{MHz}, \mathrm{CDCl}_{3}\right): \delta 8.01(\mathrm{~s}, 1 \mathrm{H}), 6.45$ $(\mathrm{s}, 2 \mathrm{H}), 5.25(\mathrm{~s}, 2 \mathrm{H}), 2.83(\mathrm{~s}, 2 \mathrm{H})$.

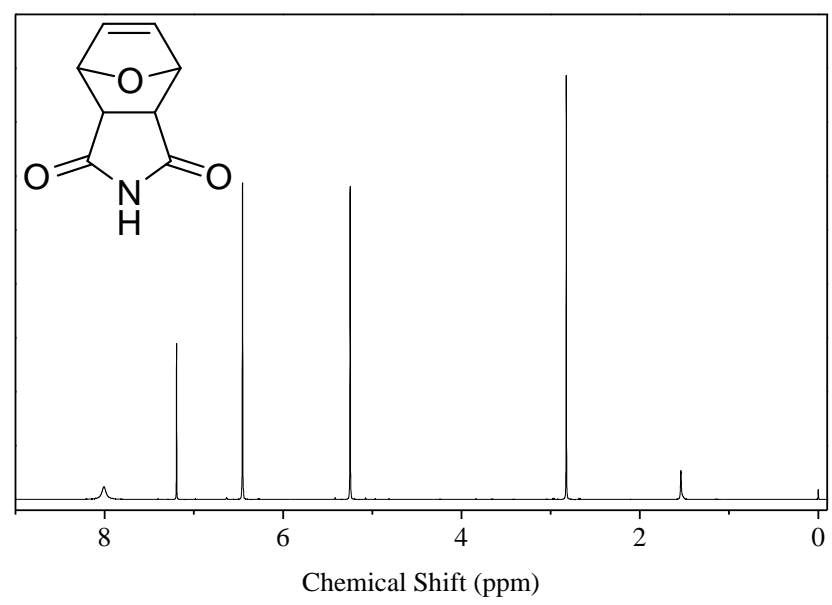


Figure S2. ${ }^{1} \mathrm{H}$ NMR spectra of compound 2 in $\mathrm{CDCl}_{3}$.

2.3 Synthesis of Compound 3.<smiles>O=C1NC(=O)C2C3C=CC(O3)C12</smiles><smiles>CC(C)(C)OC(=O)NCCCBr</smiles><smiles>CC(C)(C)OC(=O)NCCCN1C(=O)C2C3C=CC(O3)C2C1=O</smiles>

\section{Compound 3}

To a $100 \mathrm{ml}$ round bottom flask equipped with a stirbar was added $30 \mathrm{ml}$ of dimethylformamide (DMF). Next, compound 2 (14.37 g, $87 \mathrm{mmol}, 1.0$ e.q.) was added along with potassium carbonate $(48.10 \mathrm{~g}, 348$ mmol, 4.0 e.q.). The reaction mixture was heated at $50^{\circ} \mathrm{C}$ for five minutes. Finally, sodium iodide $(0.26 \mathrm{~g}$, $1.74 \mathrm{mmol}, 0.02$ e.q.) and compound 1 (21.13 g, $88.8 \mathrm{mmol}, 1.02$ e.q.) were added and stirred at $50{ }^{\circ} \mathrm{C}$ overnight. Afterwards, the reaction mixture was cooled to room temperature, diluted to $400 \mathrm{ml}$ with ethyl acetate and washed with water $(7 \mathrm{x}, 100 \mathrm{ml})$ and brine $(1 \mathrm{x}, 100 \mathrm{ml})$. The organic layer was dried with sodium sulfate, filtered, and rotovaped to yield compound 3 as a white solid. Compound 3 was purified using column chromatography and silica gel as the stationary phase, with using ethyl acetate:hexane $(1: 4, \mathrm{v} / \mathrm{v})$ as mobile phase. Chemical yield: $50 \%$, white powder. ${ }^{1} \mathrm{H} \mathrm{NMR}\left(500 \mathrm{MHz}, \mathrm{CDCl}_{3}\right) 6.45(\mathrm{~s}, 2 \mathrm{H})$, $5.20(\mathrm{~s}, 2 \mathrm{H}), 3.49(\mathrm{t}, 2 \mathrm{H}), 2.98(\mathrm{t}, 2 \mathrm{H}), 2.78(\mathrm{~s}, 2 \mathrm{H}), 1.67(\mathrm{~m}, 2 \mathrm{H}), 1.37$ (s, 9H).

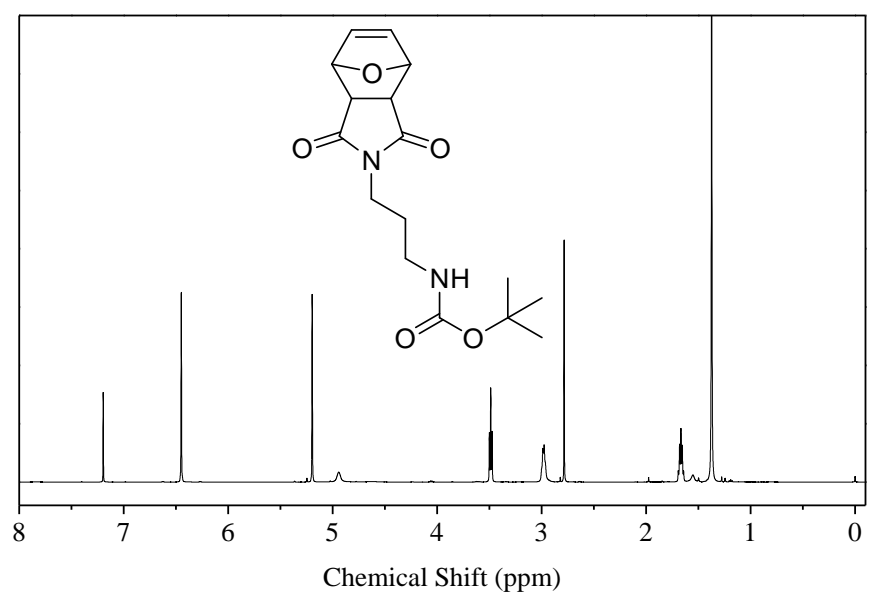

Figure S3. ${ }^{1} \mathrm{H}$ NMR spectra of compound 3 in $\mathrm{CDCl}_{3}$.

2.4 Synthesis of compound 4 


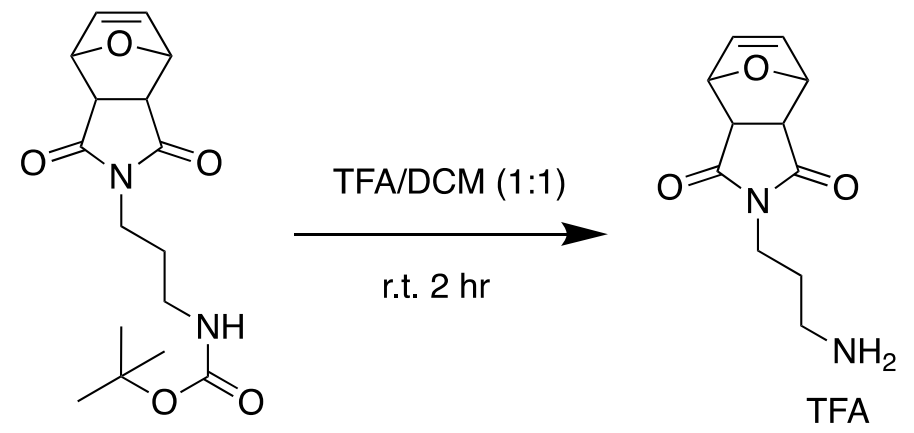

\section{Compound 4}

To a $500 \mathrm{ml}$ round bottom flask equipped with a stir-bar was added compound 3 (14.0 g, $43.4 \mathrm{mmol}, 1.0$ eq). Nitrogen was bubbled through DCM for five minutes and $35 \mathrm{ml}$ was added to the flask which was purged with nitrogen. $35 \mathrm{ml}$ of trifluoroacetic acid (TFA, excess) was added and the reaction was stirred for two hours. Afterwards, from excess diethyl ether anhydrous, filtered, washed and dried under vacum to yield a white powder. Chemical yield: $89 \%$, white powder. ${ }^{1} \mathrm{H} \mathrm{NMR}\left(500 \mathrm{MHz}, \mathrm{D}_{2} \mathrm{O}\right) 6.64(\mathrm{~s}, 2 \mathrm{H})$, $5.34(\mathrm{~s}, 2 \mathrm{H}), 3.63(\mathrm{t}, 2 \mathrm{H}), 3.16(\mathrm{~s}, 2 \mathrm{H}), 2.96(\mathrm{t}, 2 \mathrm{H}), 1.94(\mathrm{~m}, 2 \mathrm{H})$.

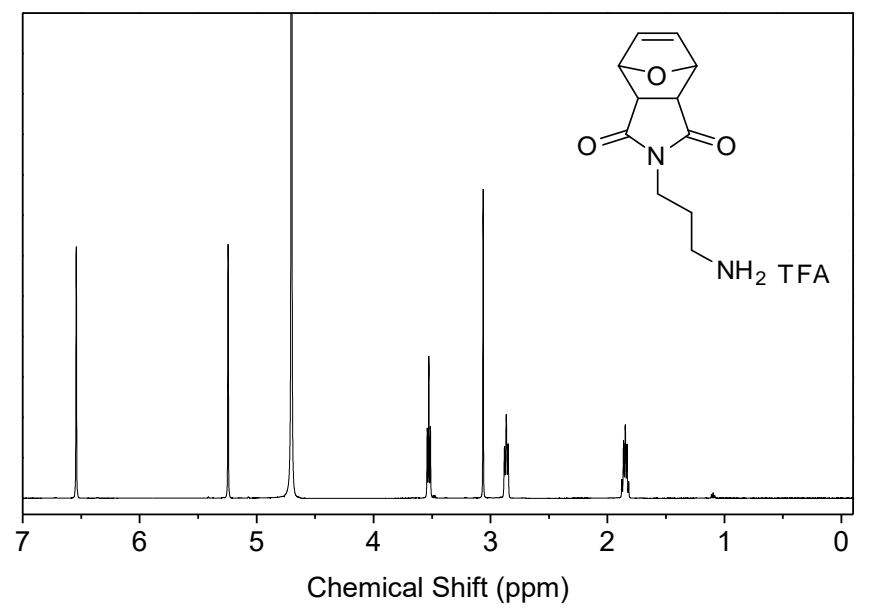

Figure S4. ${ }^{1} \mathrm{H}$ NMR spectra of compound 4 in $\mathrm{CDCl}_{3}$.

2.5 Synthesis of compound 5.<smiles>CC(C)(C)OC(=O)/N=C(\NCCCN1C(=O)C2C3C=CC(O3)C2C1=O)NC(=O)OC(C)(C)C</smiles>

Compound 5 
To a $500 \mathrm{ml}$ round bottom flask equipped with a stirbar was added compound 4 (12.0 g, $36 \mathrm{mmol}, 1.0 \mathrm{eq})$, $360 \mathrm{ml}$ acetonitrile $(\mathrm{MeCN})$, and $40 \mathrm{ml}$ of water. Triethylamine $(47 \mathrm{ml}, 335 \mathrm{mmol}, 9.2 \mathrm{eq})$ was added and finally N,N'-Di-Boc-1H-pyrazole-1-carboxamidine $(17 \mathrm{~g}, 55 \mathrm{mmol}, 1.5 \mathrm{eq})$ in portions. The reaction was allowed to stir at r.t. overnight. Afterwards, the solution was diluted with $100 \mathrm{ml}$ of ethyl acetate and extracted with water $(2 \mathrm{x}, 50 \mathrm{ml})$ and brine $(2 \mathrm{x}, 50 \mathrm{ml})$. The organic layer was dried with sodium sulfate, filtered, and rotovaped to yield compound 5. Compound 5 was purified using column chromatography and silica gel as the stationary phase to yield a white solid, with using ethyl acetate:hexane $(1: 4, \mathrm{v} / \mathrm{v})$ as mobile phase. ${ }^{2}$ Chemical yield: $90 \%$, white powder. ${ }^{1} \mathrm{H}$ NMR $\left(400 \mathrm{MHz}, \mathrm{CDCl}_{3}\right) 11.47$ (br, $\left.1 \mathrm{H}\right), 8.49$ (br, $1 \mathrm{H}), 6.51(\mathrm{~s}, 2 \mathrm{H}), 5.28(\mathrm{~s}, 2 \mathrm{H}), 3.57(\mathrm{t}, 2 \mathrm{H}), 3.39(\mathrm{t}, 2 \mathrm{H}), 2.86(\mathrm{~s}, 2 \mathrm{H}), 1.86(\mathrm{~m}, 2 \mathrm{H}), 1.49(\mathrm{~s}, 18 \mathrm{H})$.

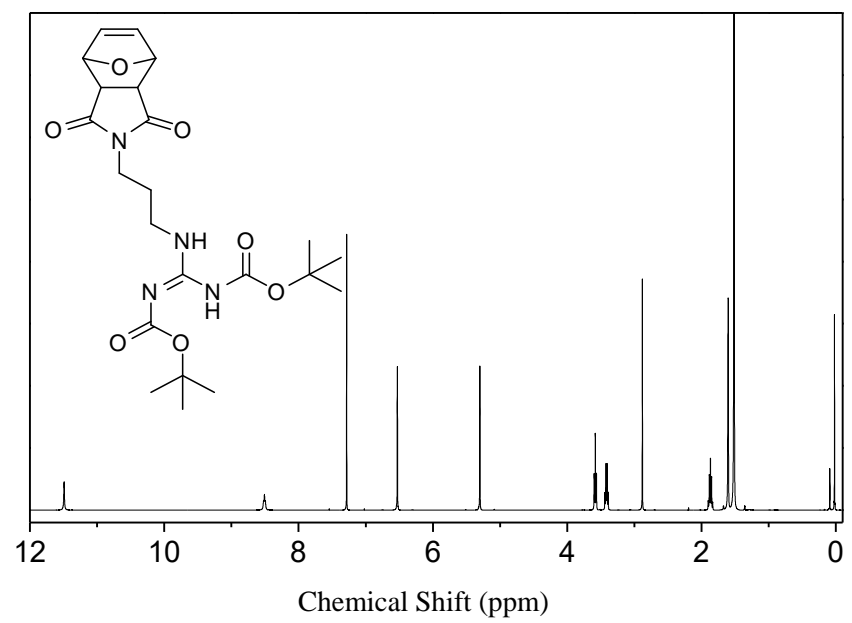

Figure S5. ${ }^{1} \mathrm{H}$ NMR spectra of compound 5 in $\mathrm{CDCl}_{3}$.

\section{Synthesis of PONI polymers.}

2.6 Ring-opening metathesis polymerization.

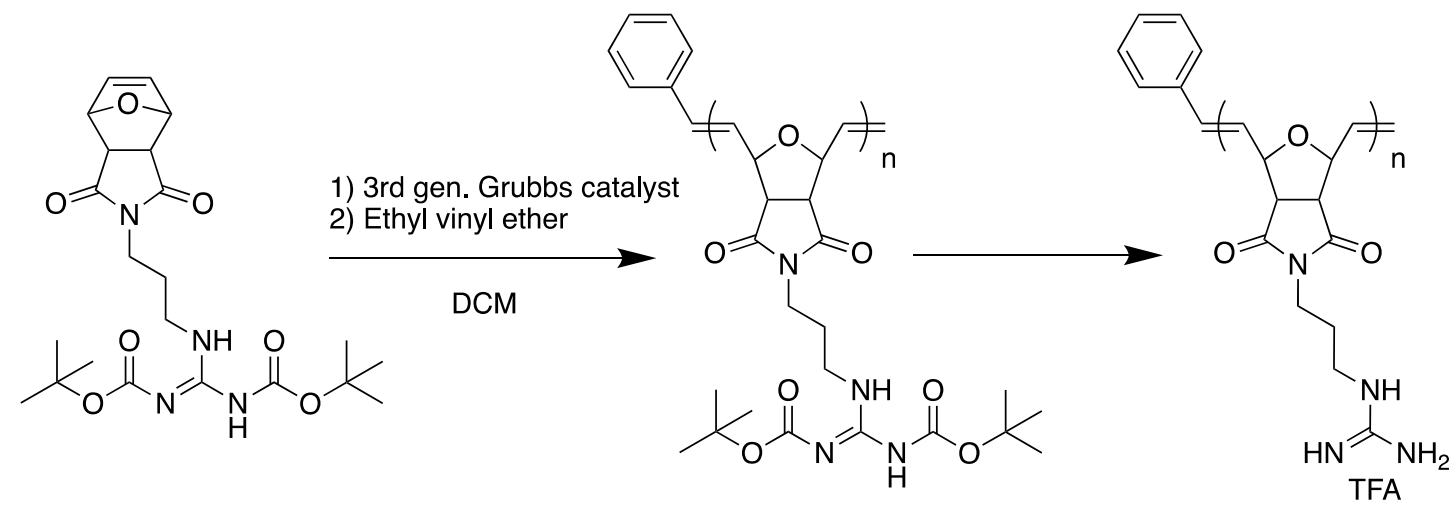

In a typical experiment, compound $5(550 \mathrm{mg}, 1.18 \mathrm{mmol})$ and $3^{\text {rd }}$ generation Grubbs catalyst (G3) (34.9 $\mathrm{mg}, 0.039 \mathrm{mmol}$ ) were weighed in separate reaction flasks and purged with $\mathrm{N}_{2}$ gas. While compound 5 were dissolved in $2 \mathrm{ml}$ of DCM, G3 was dissolved in DCM $(1 \mathrm{ml})$. Upon dissolution all the solutions were degassed by three freeze-pump-thaw cycles. After warming the solutions to room temperature, the monomer solutions and G3 solution were mixed together. The reaction mixture was stirred at room temperature for $30 \mathrm{~min}$. The reaction was terminated by the addition of excess EVE. The reaction mixture 
was further stirred for another $1 \mathrm{~h}$. The resultant polymers were precipitated from excess hexane or diethyl ether anhydrous, filtered, washed and dried under vacuum to yield a light-yellow powder. The reaction yields varied from 90 to $98 \% .{ }^{3} \mathrm{H}$ NMR (400 MHz, $\left.\mathrm{CDCl}_{3}\right) 11.57$ (s, 1H), 8.56 (br, 1H), $6.18(\mathrm{~s}, 2 \mathrm{H})$, $5.86(\mathrm{br}, 2 \mathrm{H}), 5.15(\mathrm{br}, 2 \mathrm{H}), 4.55(\mathrm{br}, 2 \mathrm{H}), 3.65(\mathrm{br}, 11 \mathrm{H}), 3.52(\mathrm{br}, 2 \mathrm{H}), 3.44(\mathrm{~s}, 2 \mathrm{H}), 1.96(\mathrm{br}, 2 \mathrm{H}), 1.72$ (br, 2H), $1.59(\mathrm{~s}, 12 \mathrm{H})$.

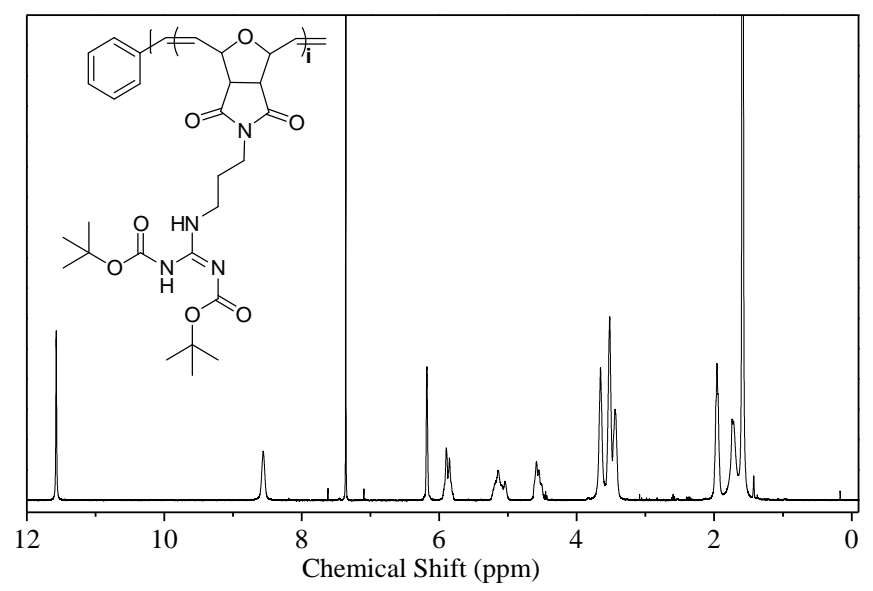

Figure S6. ${ }^{1} \mathrm{H}$ NMR spectra of polymer in $\mathrm{CDCl}_{3}$.

\subsection{Deprotection of polymers}

To a $50 \mathrm{ml}$ round bottom flask equipped with a stir-bar, Polymer $(500 \mathrm{mg})$ was added. TFE was purged with nitrogen for five minutes and $5 \mathrm{ml}$ was added to the flask. Then, $5 \mathrm{ml}$ of trifluoroacetic acid (excess) was added and the reaction was allowed to stir for two hours. Afterwards, the resultant polymers were precipitated from excess diethyl ether anhydrous, filtered, washed and dried to yield a light white powder. The reaction yields varied from 70 to $80 \%$. PONI, ${ }^{1} \mathrm{H}$ NMR $\left(400 \mathrm{MHz}, \mathrm{D}_{2} \mathrm{O}\right) 6.05(\mathrm{br}, 2 \mathrm{H}), 5.86(\mathrm{br}, 2 \mathrm{H})$, 4.94 (br, 2H), 4.56 (br,2H), 3.52 (br, 2H), 3.11 (s, 2H), 1.78 (br, 2H).

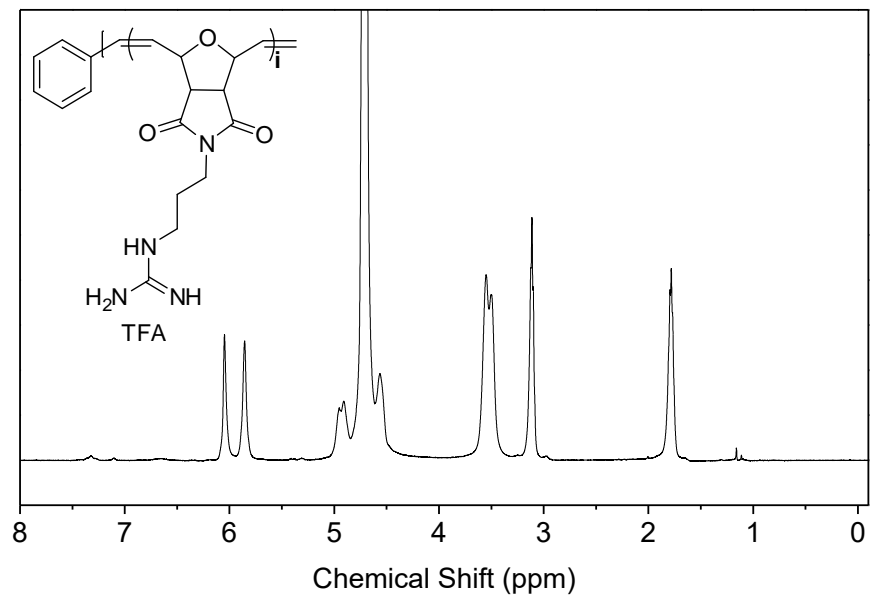

Figure S7. ${ }^{1} \mathrm{H}$ NMR spectra of PONI in $\mathrm{D}_{2} \mathrm{O}$ (It confirms complete loss of all Boc protecting groups).

\section{Characterization}

Gel permeation chromatography (GPC) were obtained using an Agilent 1260 series system equipped with a refractive index (RI) detector, a PL Gel $5 \mu \mathrm{m}$ guard column connected to $5 \mu \mathrm{m}$ analytical Mixed-C 
columns and a $5 \mu \mathrm{m}$ analytical Mixed-D column (Agilent). THF was used as the eluent with a flow rate of $1.0 \mathrm{~mL} / \mathrm{min} . \sim 3 \mathrm{mg} / \mathrm{mL}$ samples were prepared using THF as the diluent and toluene as the flow marker. All samples were filtered through $0.45 \mu \mathrm{m}$ PTFE syringe filters. Polystyrene standards were used for the calibration.

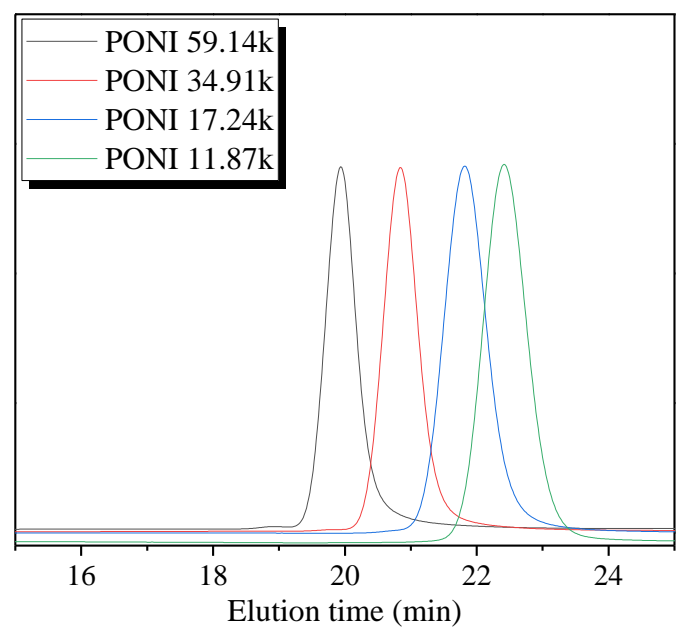

Figure S8. GPC traces of polymer 1 with THF as the eluent at a rate of $1 \mathrm{~mL} / \mathrm{min}$.

\section{Recombinant protein expression}

A series of glutamic acid residues (E-tag) was inserted in the C-terminus of GFP according to our previously reported method. ${ }^{4}$ Similarly, an E20 tag was inserted in tdTomato (C-terminus) (Addgene plasmid id: 30530), and an E10 tag was inserted in Cre recombinase (N-terminus) (Addgene plasmid id: 36915) through restriction cloning and site-directed mutagenesis. Recombinant proteins were expressed in an E. coli BL21 DE3 PlysS strain using standard protein expression protocol. Briefly, protein expression was carried out in $2 \times$ YT media with an induction condition of $1 \mathrm{mM} \mathrm{IPTG}$ and $18 / 25^{\circ} \mathrm{C}$ for $16 \mathrm{~h}$. At this point, the cells were harvested, and the pellets were lysed using $1 \%$ Triton-X-100 (30 min, $\left.37{ }^{\circ} \mathrm{C}\right) / \mathrm{DNase}-$ I treatment (10 $\mathrm{min})$. Proteins were purified using HisPur cobalt columns. After elution, proteins were preserved in PBS buffer containing $300 \mathrm{mM}$ salt. The purity of native proteins was determined using $12 \%$ SDS-PAGE gel.

\section{PPNC preparation, characterization, and instrumentation}

PONI polymer/E-tag protein nanocomposites (PPNCs) were prepared in polypropylene microcentrifuge tubes (Fisher) through a simple mixing procedure. PPNCs were incubated at RT for at least $\sim 10$ minutes prior to DLS analysis. For long-term stability studies, incubation was performed at $37{ }^{\circ} \mathrm{C}$ under an atmosphere of 5\% CO2. Size measurements were conducted using a Malvern Zetasizer Nano-ZS. AlamarBlue (ThermoFisher) viability studies were performed using a Molecular Devices Spectramax M2 with accompanying SoftMax Pro 7 software.

TEM imaging of nanoassemblies was performed as follows: the freshly prepared sample solution was drop-cast onto a 400 mesh copper grid (Electron Microscopy Sciences), and the sample was allowed to dry at room temperature overnight. The samples were then inspected using a JEOL 2000FX TEM with an accelerating voltage of $200 \mathrm{kV}$. 


\section{Cell culture and MFI determination by flow cytometry}

HEK-293T and HeLa cells (ATCC) were cultured in high glucose (4.5 g/L) DMEM (Gibco), supplemented with 10\% (v/v) FBS (Gibco), and 1\% antibiotics (Antibiotic-Antimycotic, Corning). For Cre-E10 delivery, loxP-DsRed-STOP-loxP-GFP (HEK-293T) cells were generated as previously reported.Error! Bookmark not defined. Cells were placed and incubated at $37{ }^{\circ} \mathrm{C}$ with $5 \% \mathrm{CO} 2$ and seeded $24 \mathrm{~h}$ prior to experimentation. On the day of the experiment, PPNCs were formulated and then added dropwise to the cells ( $9 \times 10^{4}$ cells/well; $500 \mu \mathrm{L}$ total volume) in a 24 -well plate. Cells were washed with $1 \times$ PBS (twice) and then trypsinized. Cells were then preserved by fixation with PFA (2\%) for $\sim 20$ minutes at $4^{\circ} \mathrm{C}$, and finally stored in modified flow buffer (PBS $+0.5 \%$ BSA, $0.25 \% \mathrm{NaN} 3,2 \mathrm{mM}$ EDTA). Flow cytometry was performed using a BD Dual LSRFortessa flow cytometer. Data analysis to quantify the values mean fluoresce intensity (MFI) was performed using FACSDiva software (Becton Dickinson).

\section{Cytosolic delivery evaluation by flow imaging cytometry}

Flow imaging techniques utilized an Amnis ImageStream MkII Imaging Flow Cytometer (Luminex). Cells were placed and incubated at $37{ }^{\circ} \mathrm{C}$ with $5 \% \mathrm{CO} 2$ and passaged $24 \mathrm{~h}$ prior to experimentation. PPNCs were formulated and then added dropwise to the cells $\left(9 \times 10^{4}\right.$ cells/well; $500 \mathrm{~L}$ total volume $)$ in a 24-well plate. Cells were washed with $1 \times$ PBS (twice) and then trypsinized. After cell were resuspensed in the modified flow buffer, $0.75 \mu \mathrm{L}$ of $10 \mu \mathrm{M}$ DRAQ5 fluorescent probe (Thermo Fisher) was added and allowed to incubate for $\sim 20$ minutes. Cells were then processed at a flow rate of 1,200 cells $/ \mathrm{sec}$ and images were taken with $60 \mathrm{X}$ magnification.

Data were analyzed by Amnis IDEAS software. Focused cell images were isolated through a Gradient RMS histogram of the widefield (Ch01). Single cells were then isolated using a scatterplot of Aspect Ratio vs. Area of the widefield (Ch01). At this point, the internalization wizard provided by the software was utilized as a preliminary gate during the screening process. This wizard utilizes a two-stage process to (1) select the entire population of cell images which could be considered GFP+ above a certain userdefined threshold (determined through comparison to a cell-only sample), and (2) select the population of cells which are defined as internalized by the user, based on an 'internalization' binary with a modified 'erode' mask provided by the software. This isolated population is hereon termed 'internalized'. Nuclear co-localization was determined using a scatterplot between the centroid of $\mathrm{Ch02}$ and the centroid of DRAQ5 nuclear stain fluorescence (Ch05). This gating stage was manually confirmed by the user and provided an excellent separation between endosomal/surface-bound cells and cells with nuclear GFP localization.

\section{Mammalian cell viability assay for PONI polymers}

HeLa cells (ATCC CCL-2) were seeded at $1.5 \times 10^{4}$ cells/well $24 \mathrm{~h}$ prior to the experiment and were cultured in Dulbecco's modified Eagle medium (DMEM; ATCC 30-2002) with 10\% bovine calf serum and $1 \%$ antibiotics at $37^{\circ} \mathrm{C}$ in a humidified atmosphere of $5 \% \mathrm{CO}_{2}$ for $48 \mathrm{~h}$. Different concentrations of each of the polymers were prepared ranging from 15.6-8000 $\mathrm{nM}$ in serum media followed by their addition to the seeded cells. After $24 \mathrm{~h}$ of incubation (37C under a humidified atmosphere of $5 \% \mathrm{CO}_{2}$ ), cell viability was determined using alamarBlue according to the manufacturer's protocol (Invitrogen). After a wash step with PBS three times, cells were treated with $220 \mu \mathrm{L}$ of $10 \%$ alamarBlue in serum containing media and incubated at $37{ }^{\circ} \mathrm{C}$ under a humidified atmosphere of $5 \% \mathrm{CO} 2$ for $3 \mathrm{~h}$. After incubation, $200 \mu \mathrm{L}$ of solution from each well was transferred in a 96-well black microplate. Red 
fluorescence, resulting from the reduction of Alamar blue solution, was quantified (excitation/emission: $560 \mathrm{~nm} / 590 \mathrm{~nm}$ ) on a SpectraMax M2 microplate reader (Molecular Device) to determine the cellular viability. Cells without any PNPs were considered as $100 \%$ viable. Each experiment was performed in quadruplets. Error bars in the graphs represent standard deviations (population) in the measurements.

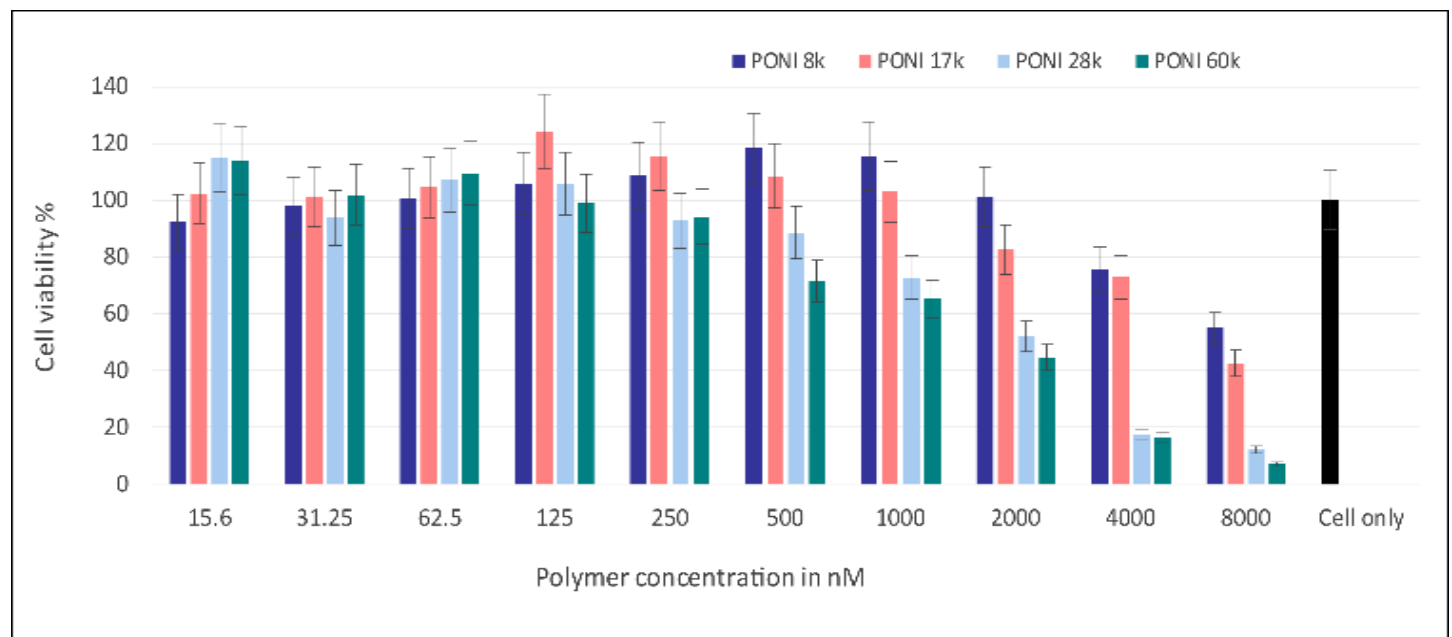

Supplementary Figure S9: Cytotoxicity of PONI polymers of varying molecular weight against HeLa cells.
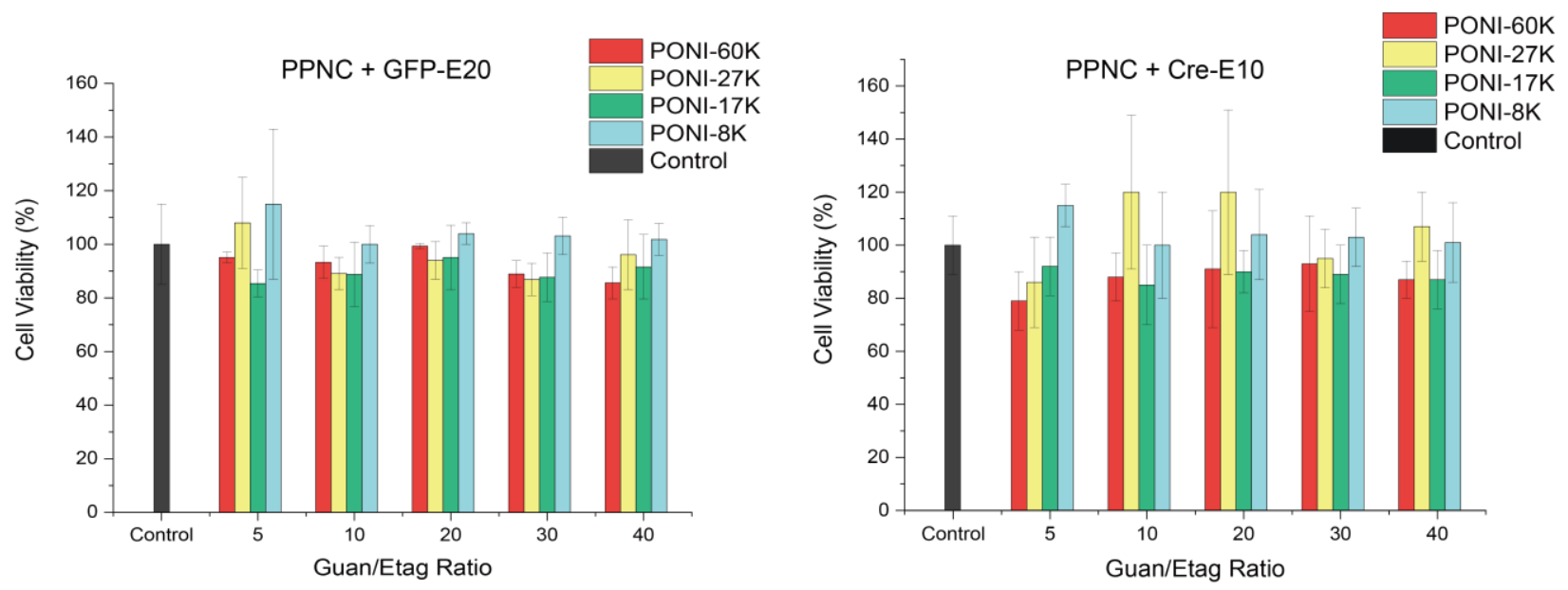

Supplementary Figure S10: Cytotoxicity of PPNC of varying molecular weight PONI(562.5 nM) and Etag proteins against HeLa cells. 


\section{Polymer-protein Guan/E-tag formulations}

\begin{tabular}{|l|l|l|l|l|l|l|l|l|}
\hline G/E ratio & 1.00 & 5.00 & 10.00 & 20.00 & 30.00 & 40.00 & 50.00 & 60.00 \\
\hline PONI-8K(nmol) & 1.125 & 1.125 & 1.125 & 1.125 & 1.125 & 1.125 & 1.125 & 1.125 \\
\hline E20GFP(nmol) & 1.69 & 0.34 & 0.17 & 0.08 & 0.06 & 0.04 & 0.03 & 0.03 \\
\hline mol ratio & 0.67 & 3.33 & 6.67 & 13.33 & 20.00 & 26.67 & 33.33 & 40.00 \\
\hline
\end{tabular}

\begin{tabular}{|l|l|l|l|l|l|l|l|l|}
\hline G/E ratio & 1.00 & 5.00 & 10.00 & 20.00 & 30.00 & 40.00 & 50.00 & 60.00 \\
\hline PONI-17K(nmol) & 1.125 & 1.125 & 1.125 & 1.125 & 1.125 & 1.125 & 1.125 & 1.125 \\
\hline E20GFP(nmol) & 3.54 & 0.71 & 0.35 & 0.18 & 0.12 & 0.09 & 0.07 & 0.06 \\
\hline mol ratio & 0.32 & 1.59 & 3.17 & 6.35 & 9.52 & 12.70 & 15.87 & 19.05 \\
\hline
\end{tabular}

\begin{tabular}{|l|l|l|l|l|l|l|l|l|}
\hline G/E ratio & 1.00 & 5.00 & 10.00 & 20.00 & 30.00 & 40.00 & 50.00 & 60.00 \\
\hline PONI-27K(nmol) & 1.125 & 1.125 & 1.125 & 1.125 & 1.125 & 1.125 & 1.125 & 1.125 \\
\hline E20GFP(nmol) & 5.63 & 1.13 & 0.56 & 0.28 & 0.19 & 0.14 & 0.11 & 0.09 \\
\hline mol ratio & 0.20 & 1.00 & 2.00 & 4.00 & 6.00 & 8.00 & 10.00 & 12.00 \\
\hline
\end{tabular}

\begin{tabular}{|l|l|l|l|l|l|l|l|l|}
\hline G/E ratio & 1.00 & 5.00 & 10.00 & 20.00 & 30.00 & 40.00 & 50.00 & 60.00 \\
\hline PONI-60K(nmol) & 1.125 & 1.125 & 1.125 & 1.125 & 1.125 & 1.125 & 1.125 & 1.125 \\
\hline E20GFP(nmol) & 12.54 & 2.51 & 1.25 & 0.63 & 0.42 & 0.31 & 0.25 & 0.21 \\
\hline mol ratio & 0.09 & 0.45 & 0.90 & 1.79 & 2.69 & 3.59 & 4.48 & 5.38 \\
\hline
\end{tabular}

Supporting Table 1-4: Formulation conditions for PONI polymers with GFPE20 at varying Guan/E-tag ratios. All values represent a preparation of PPNCs at working concentration, with a final volume of 2 $\mathrm{mL}$. Note that preparation was done as described in Methods.

\section{PPNC size characterization by DLS}

Polymer-GFPE20 PPNCs were formed as described, through simple mixture between PONI polymer and protein, and incubated at RT for $\sim 10$ minutes. Volume was then made up to $150 \mu \mathrm{L}$ with HyClone PBS (150 mM, GE). Finally, DMEM (low glucose, $1 \mathrm{~g} / \mathrm{L}$, Gibco) containing 10\% FBS (Gibco) was added to make the final volume to $2 \mathrm{~mL}$. These PPNCs were incubated for $\sim 10$ minutes prior to analysis. Detailed experimental considerations can be found in Methods. 


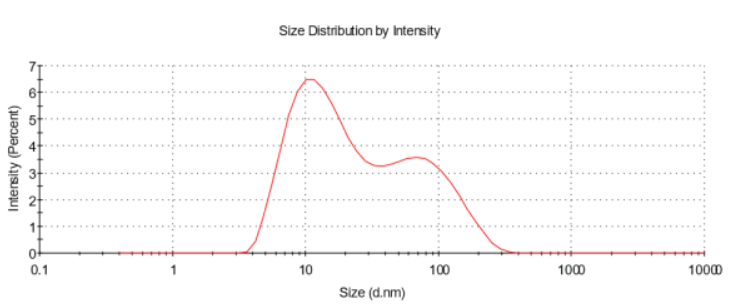

DMEM Low Glucose

$+10 \%$ FBS

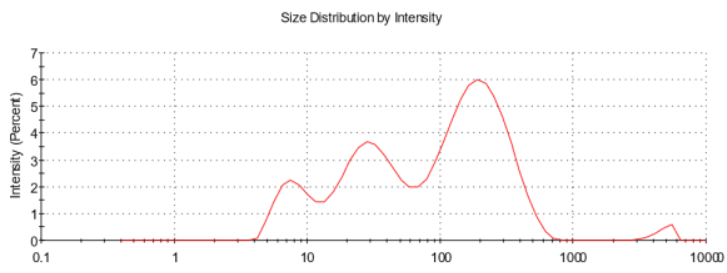

PONI-60k, Guan/E-tag ratio: 1 size (d.nm)

DMEM Low Glucose

$+10 \%$ FBS

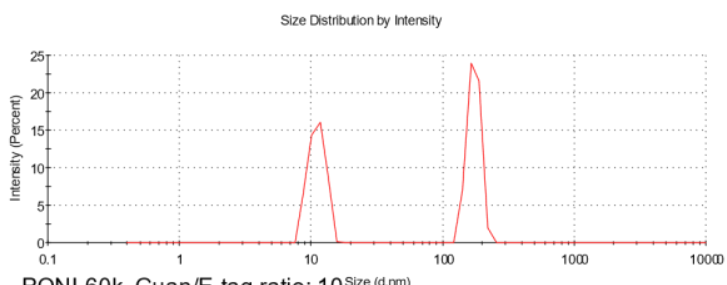

PONI-60k, Guan/E-tag ratio: $10^{\text {Size (d.nm) }}$

DMEM Low Glucose

$+10 \%$ FBS

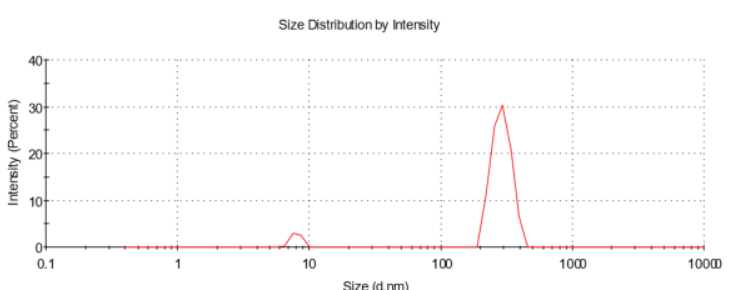

PONI-60k, Guan/E-tag ratio: $30^{\text {Size (d.nm) }}$

DMEM Low Glucose

$+10 \%$ FBS

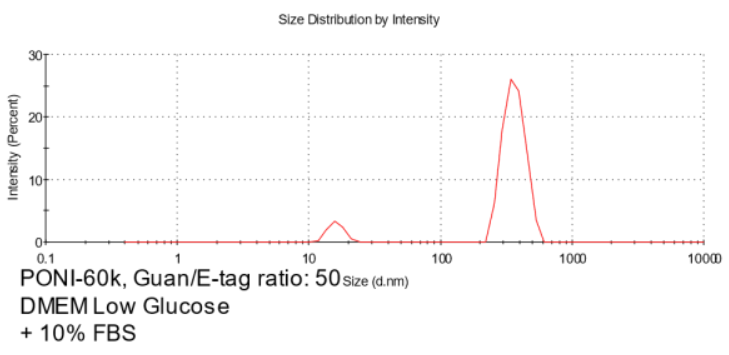

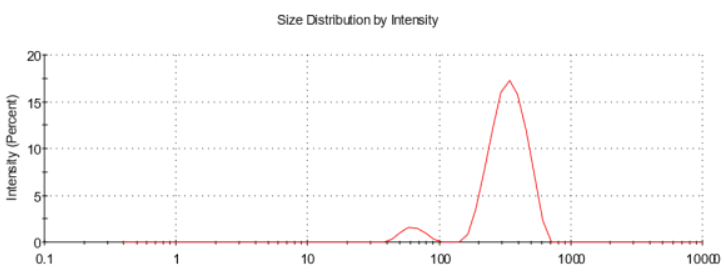

PONI-27k, Guan/E-tag ratio: $10^{\text {Size (d.nm) }}$

PBS (150 mM)

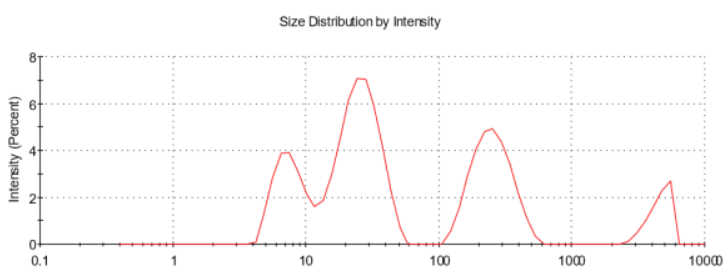

PONI-27k, Guan/E-tag ratio: 1 size (d.nm)

DMEM Low Glucose

$+10 \%$ FBS
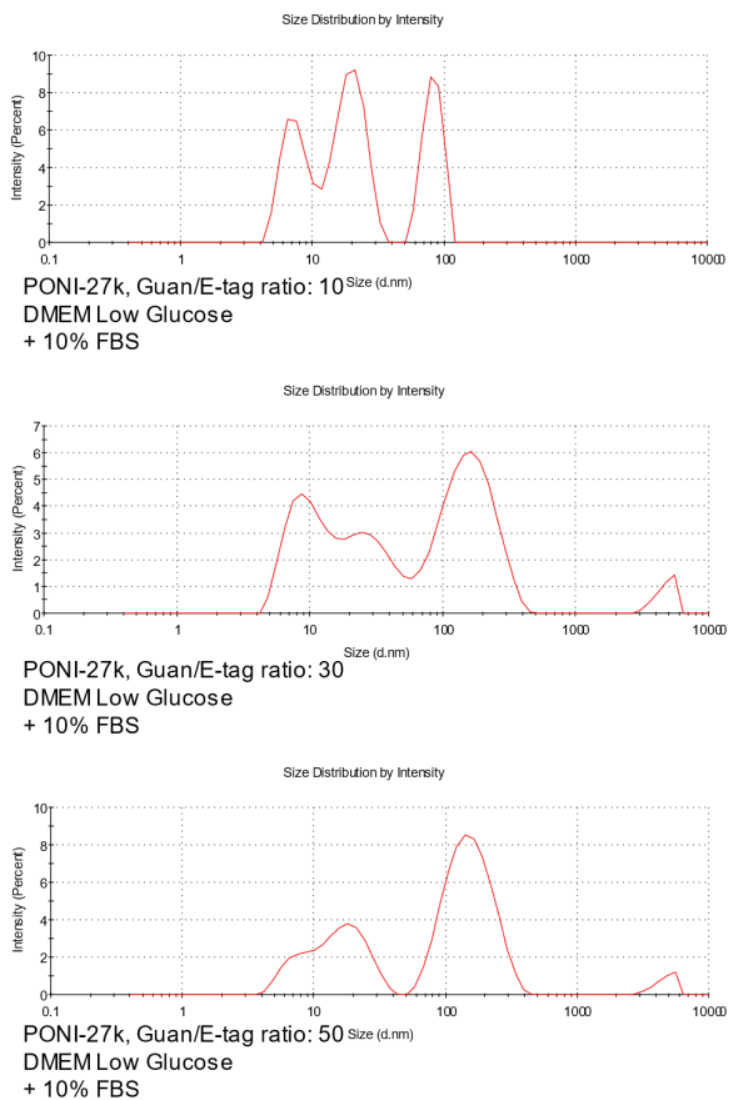

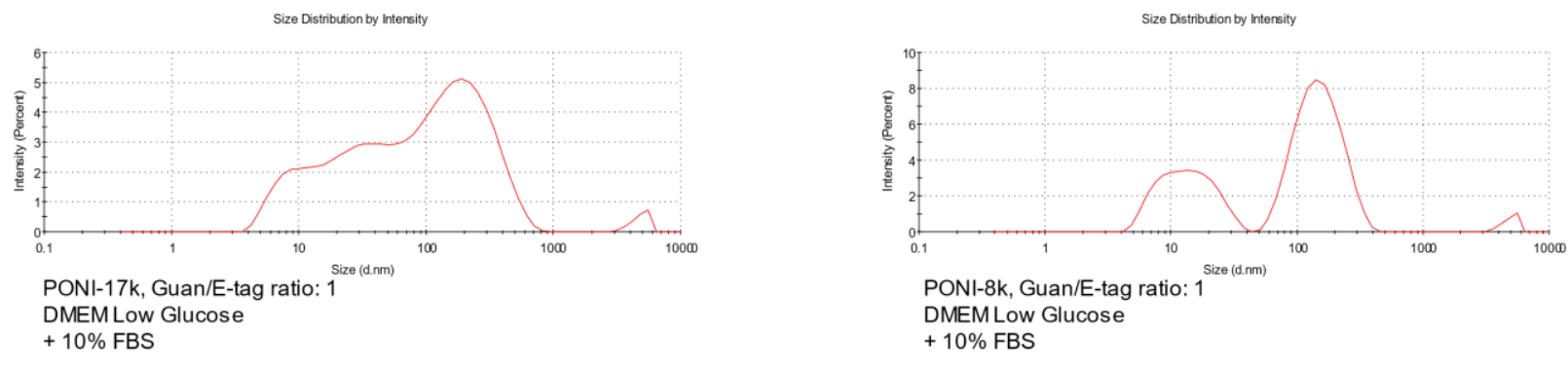

PONI-8k, Guan/E-tag ratio: $1^{\text {Size (d.nm) }}$

DMEM Low Glucose

$+10 \%$ FBS
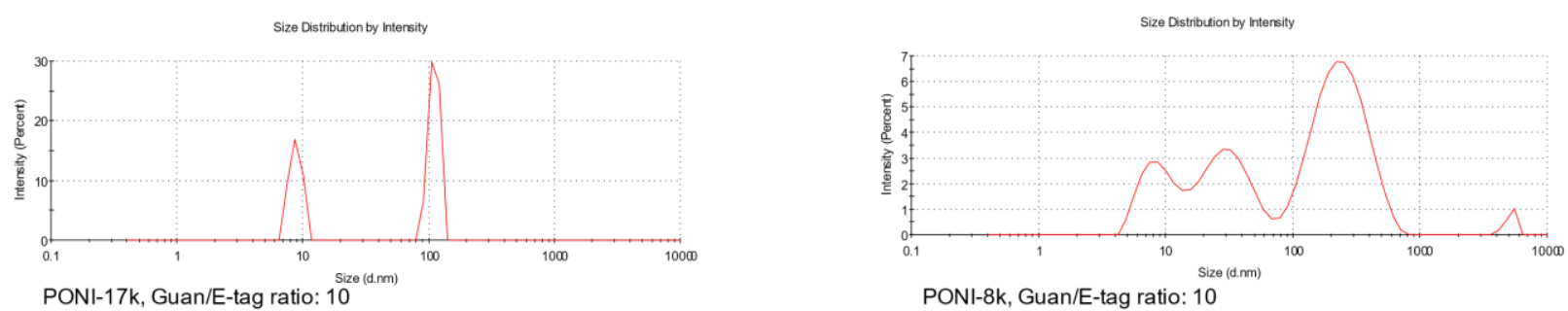

PONI-8k, Guan/E-tag ratio: 10 DMEM Low Glucose DMEM Low Glucose $+10 \%$ FBS

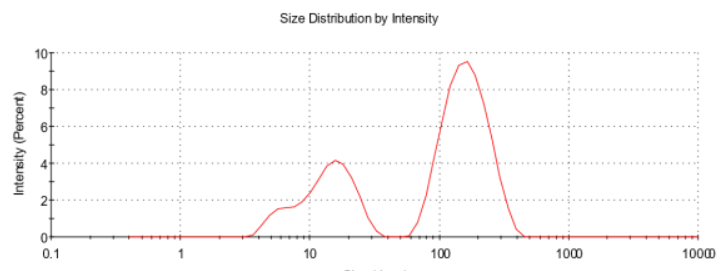
$+10 \%$ FBS

PONI-17k, Guan/E-tag ratio: $30^{\text {Size (d.nm) }}$ DMEM Low Glucose $+10 \%$ FBS
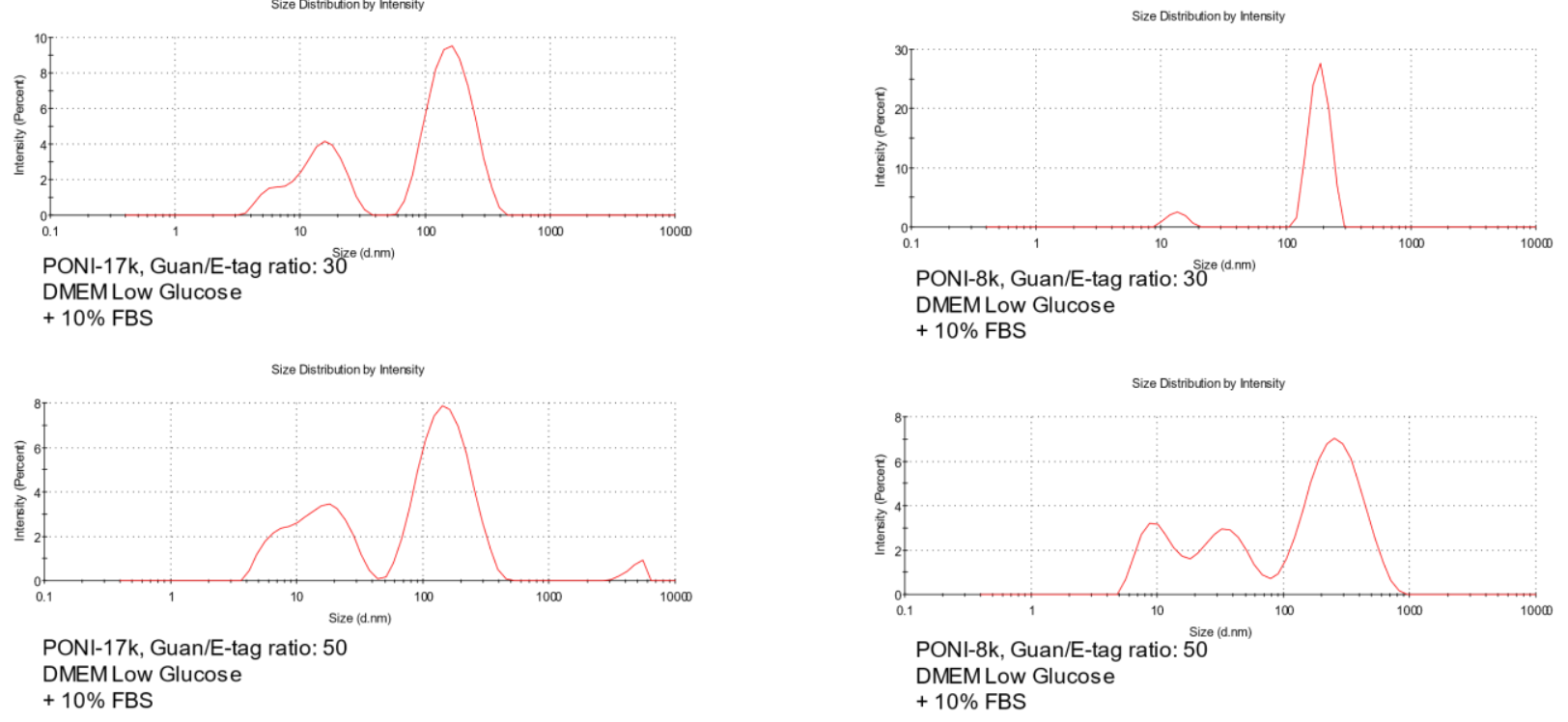

Supporting Figure S11: Representative DLS spectra (intensity) for all 4 PONI homopolymers and GFPE20 with Guan/E-tag ratios of 1, 10, 30, and 50. Spectra are included for DMEM+10\% FBS alone as well as PONI-27k at a Guan/E-tag ratio of 10 in PBS. The presence of serum proteins complicates these spectra. However, based on differences with FBS alone, the peak arising between 100-500 nm represents the PPPNC population.

\section{PPNC 24-h size stability in serum}

PPNCs were prepared using GFPE20 and PONI-60k at a Guan/E-tag ratio of 10, which was previously shown to elicit the formation of discrete assemblies. The size of the peak corresponding to PPNCs was tracked at discrete intervals across a range of 24 hours and showed minimal increase in hydrodynamic 
size.

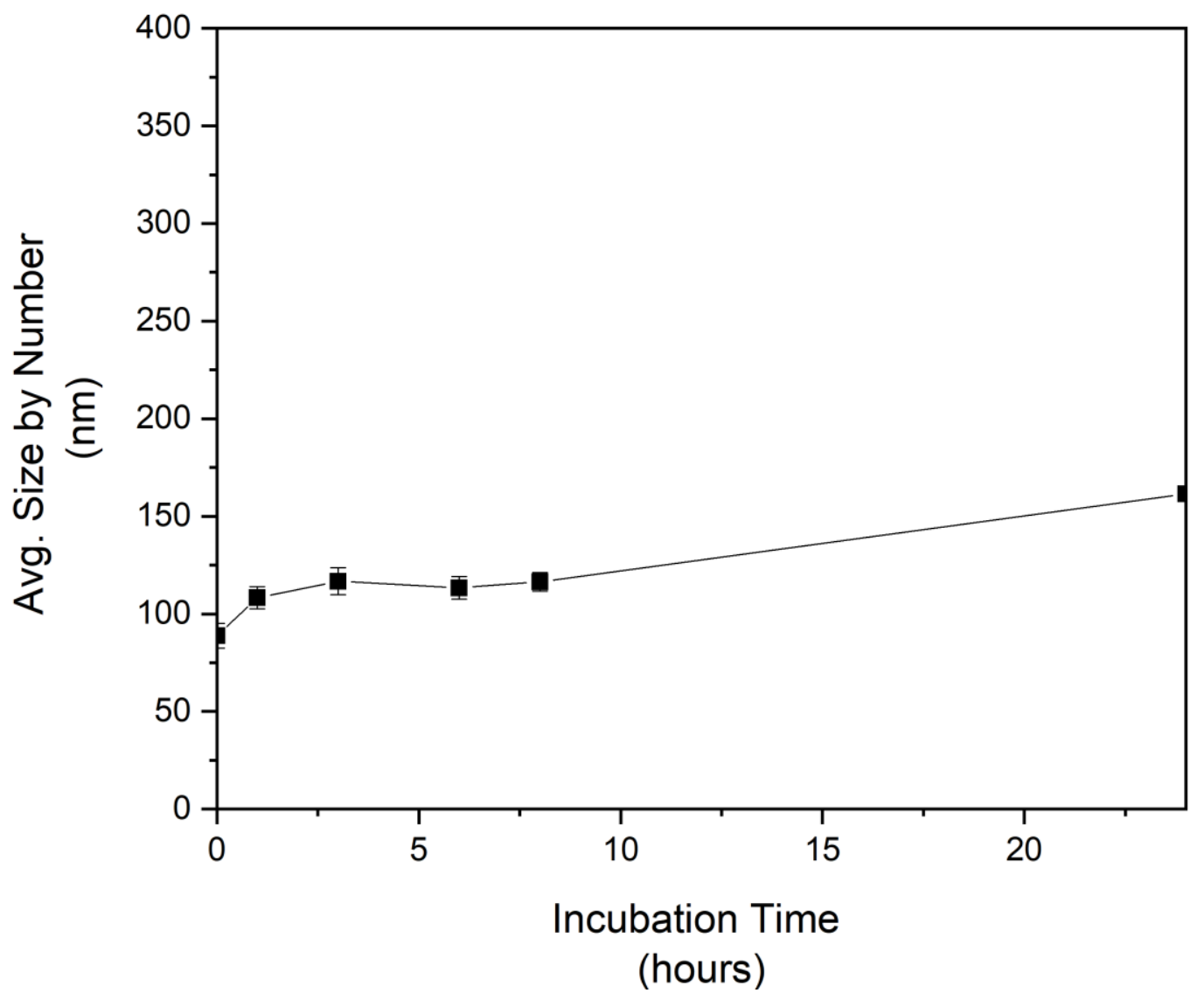

Supplementary Figure S12: PPNC size stability over a 24-hour incubation period, based on DLS measurement.

\section{Confocal microscopy and time lapse imaging}

Confocal microscopy imaging was performed using a Nikon A1 Spectral Detector Confocal. For all confocal studies, $1.5 \times 10^{5}$ cells were seeded in \#1.5 circular confocal dishes (Mattek) for imaging $24 \mathrm{~h}$ prior. Time-lapse real-time video imaging was performed over a 3-hour time course and processed using the NISElements Advanced Research software (Nikon). Videos were cropped and pixels were resized using a linear smoothing method to prevent pixelated annotations. Confocal microscopy was used to assess Cre activity by validating GFP+ cells following recombination. Quantification of GFP expressing cells was performed using Image $(n=6)$.

\section{Imaging flow cytometry representative processing spectra}

Flow imaging (Amnis ImageStream Mark II Imaging Flow Cytometer) was performed according to standard instrumentation protocol from Amnis. Analysis was performed using the gating method described in Methods. 

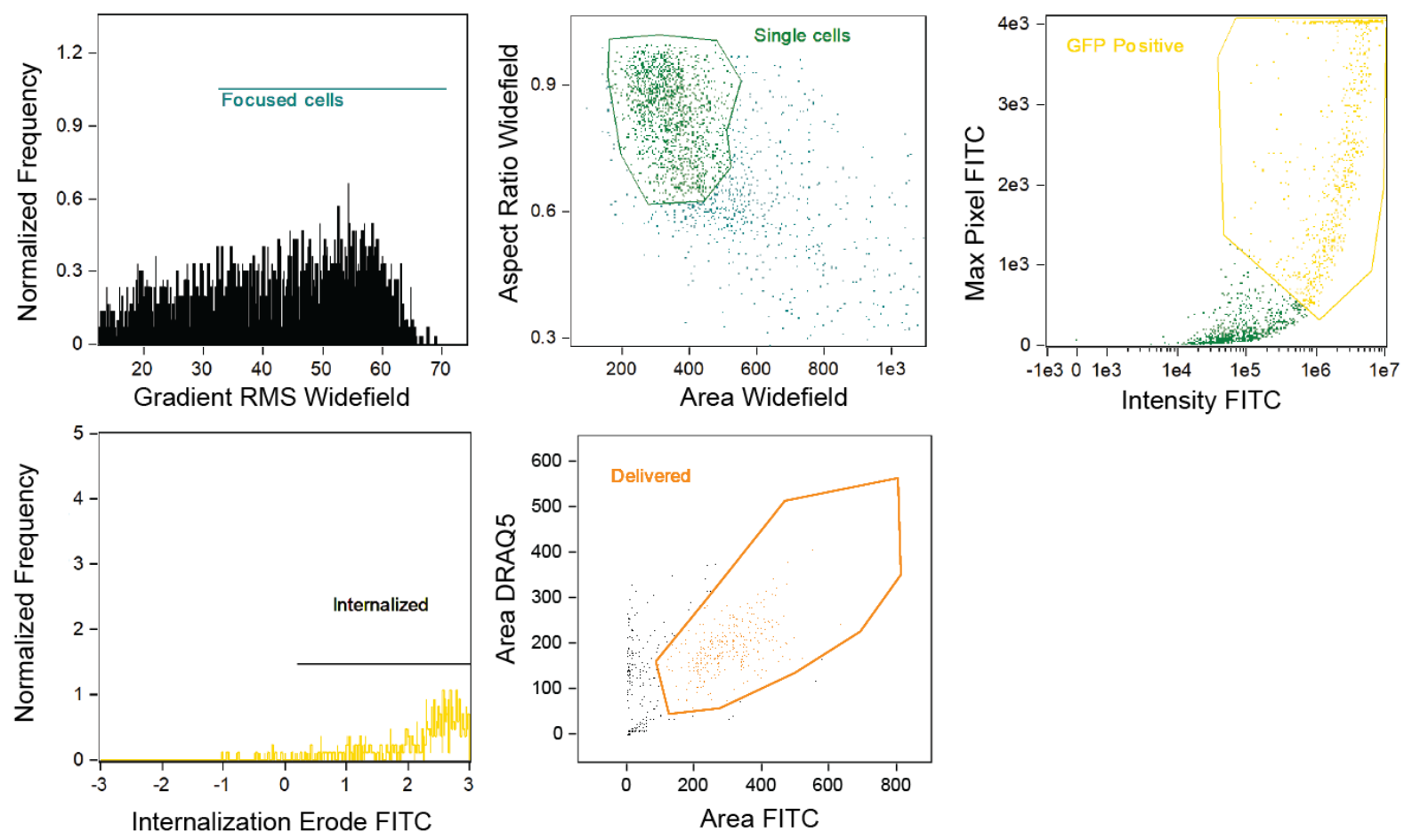

Supplementary Figure S13: Gating and the analysis of the flow imaging cytometry data. Representative spectra for each step are shown. Axis titles have been altered for clarity.

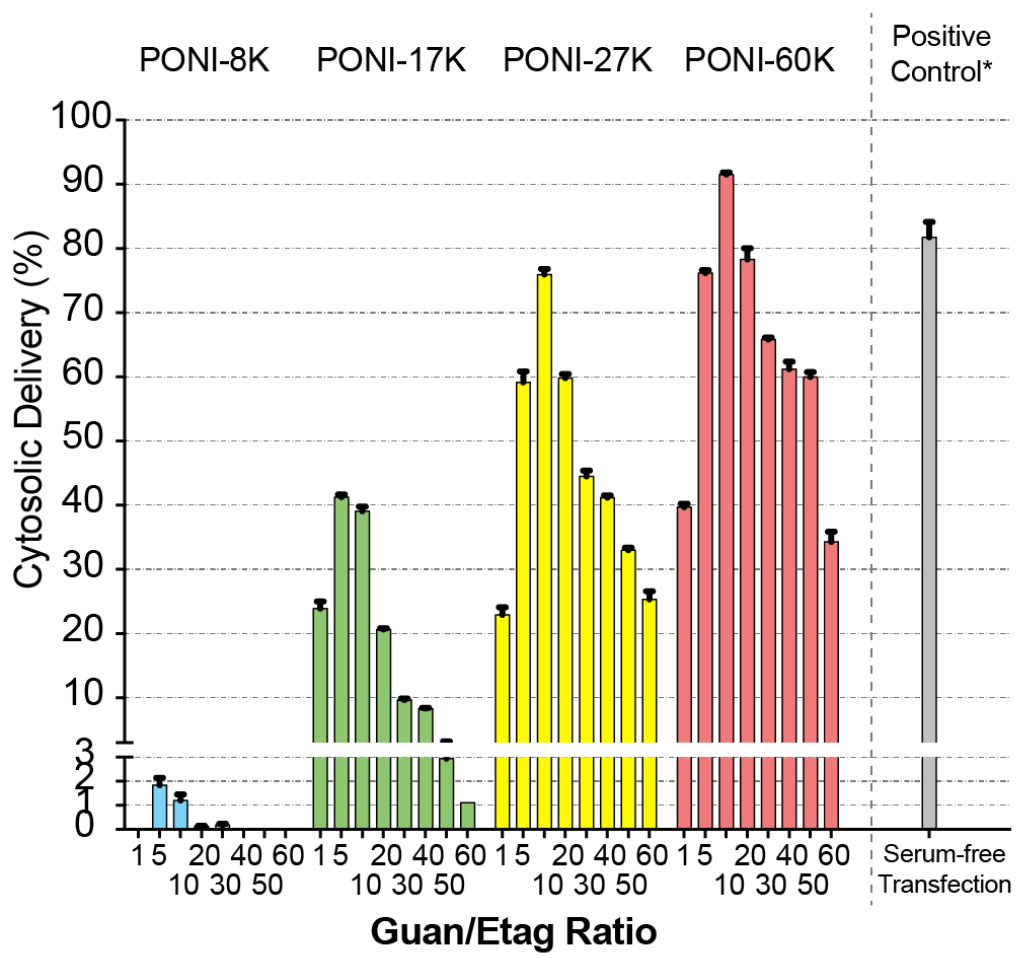


Supplementary Figure S14: Percentages of total cell populations with cytosolic delivery of GFP, compared with a Thermo Scientific ${ }^{\mathrm{TM}}$ Pierce ${ }^{\mathrm{TM}}$ Protein transfection kit, as determined by flow imaging cytometry. Notably, the serum-free condition was followed according to the manufacturer's protocol. (Thermo Fisher Scientific)

\section{Uptake mechanism evaluation through endocytic inhibition}

HEK-293T cells were seeded at $1.5 \times 10^{5}$ cells/well $48 \mathrm{~h}$ prior to the experiment in $35 \mathrm{~mm} \# 1.5$ confocal dishes (Mattek) and cultured in Dulbecco's modified Eagle medium (DMEM; ATCC 30-2002) with 10\% bovine calf serum and $1 \%$ antibiotics at $37^{\circ} \mathrm{C}$ in a humidified atmosphere of $5 \% \mathrm{CO}_{2}$. Cells were washed with PBS once and then cultured in media containing a dissolved quantity of small molecule inhibitor, wortmannin $(150 \mathrm{ng} / \mathrm{mL})$, chlorpromazine $(1.5 \mu \mathrm{g} / \mathrm{mL})$, or methyl- $\beta$-cyclodextrin $(7.5 \mathrm{mg} / \mathrm{mL})$ for 1 hour at $37^{\circ} \mathrm{C}, 5 \% \mathrm{CO}_{2}$. After this treatment, cells were washed with PBS twice, and then delivery was performed using PONI-60k at a Guan/E-tag ratio of 10. Delivery was performed over a $24 \mathrm{~h}$ incubation period, after which cells were washed with PBS and imaged by confocal; a-d display representative delivery images for each condition. NIS-Elements Advanced Research software (Nikon) was used to process the data and determine delivery efficiency (\%). 6 representative images were acquired for each inhibitor, and data displayed in e) represents the population average, with error bars representing standard deviation (population).
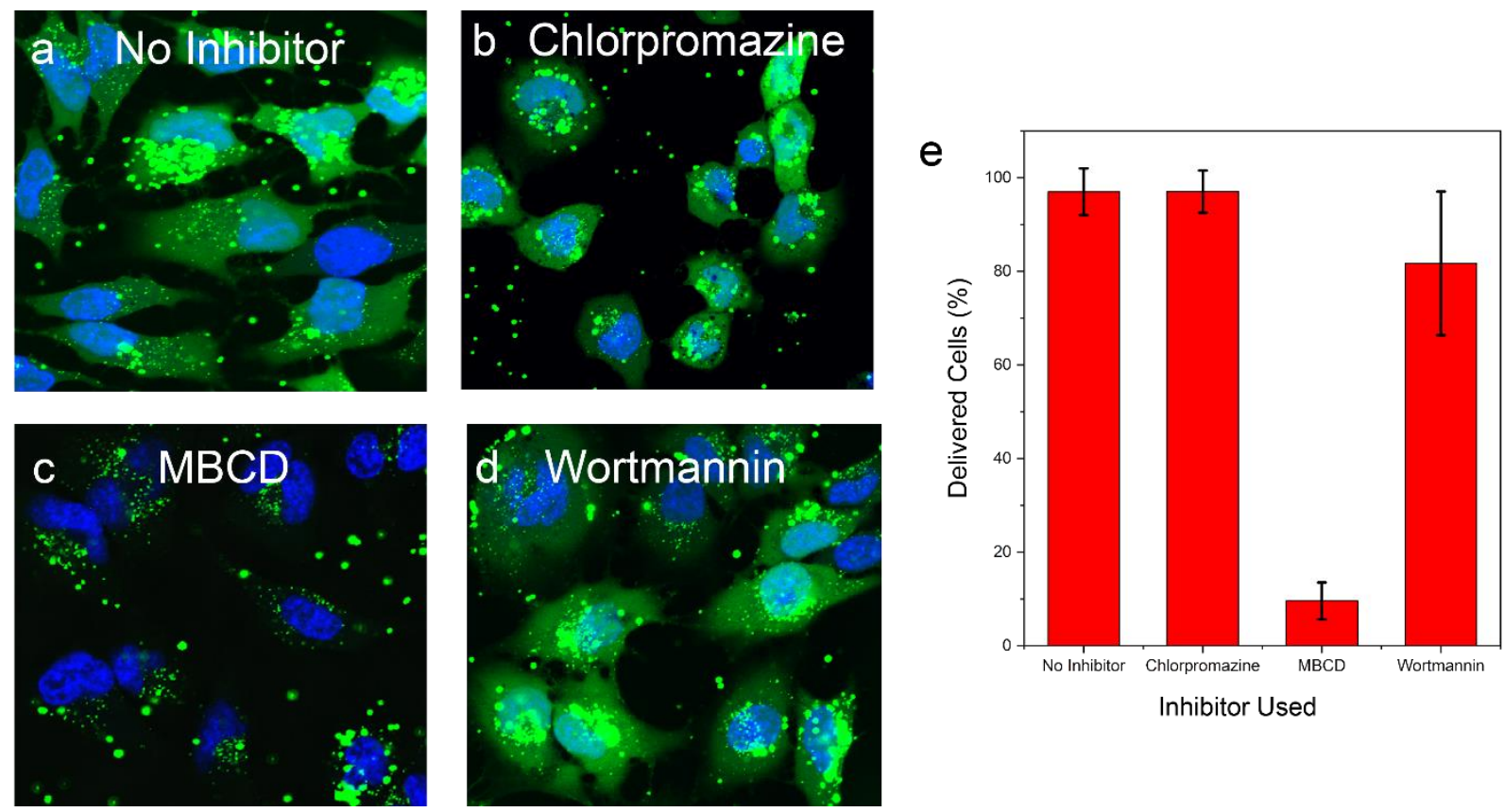

Supplementary Figure S15. Representative confocal images of HEK-293T cells pre-treated with various inhibitors. Delivery was performed using PONI-60k at a Guan/E-tag ratio of 10. Similar trends were observed for other PONI homopolymers (data not shown). 


\section{Cytosolic delivery evaluation with different length of E-tag GFPs}

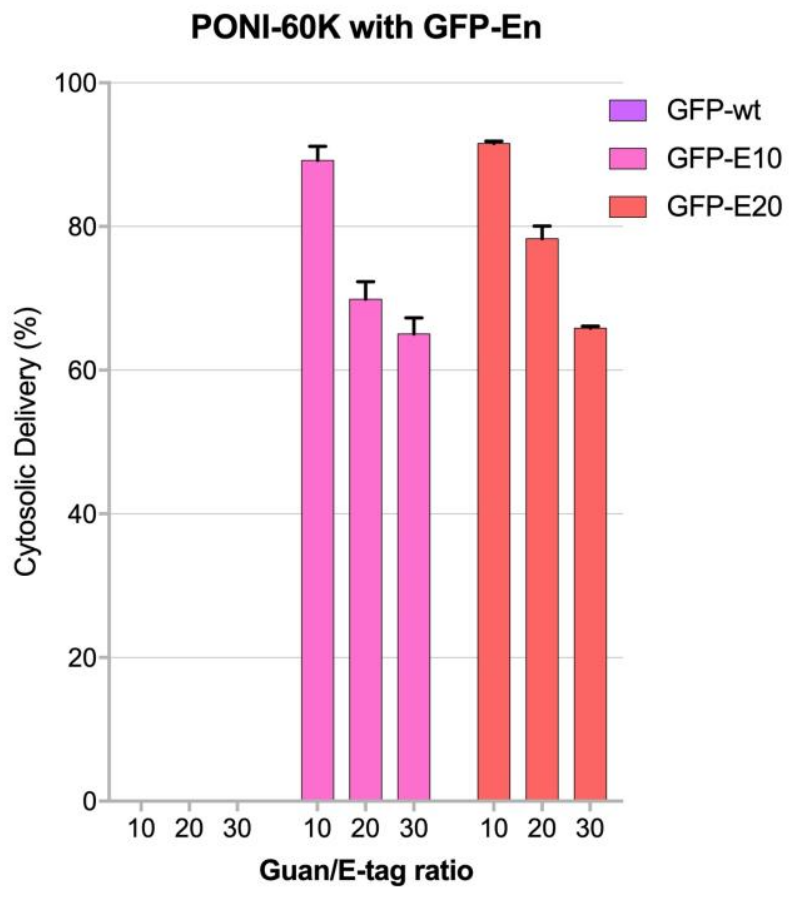

Supplementary Figure S16: Percentages of total cell populations with cytosolic delivery of GFP-wt, GFPE10, and GFP-E20, as determined by flow imaging cytometry.

\section{Confocal Large Imaging of HEK-293T LoxP-dsRed-STOP-LoxP-EGFP Reporter Delivery}

Cre recombinase reporter HEK-293T cell line containing a LoxP-dsRed-STOP-LoxP-EGFP motif was seeded at $5 \times 10^{4}$ cells/well $24 \mathrm{~h}$ prior to the experiment in $35 \mathrm{~mm} \# 1.5$ confocal dishes (Mattek) and cultured in Dulbecco's modified Eagle medium (DMEM; ATCC 30-2002) with 10\% bovine calf serum and $1 \%$ antibiotics at $37{ }^{\circ} \mathrm{C}$ in a humidified atmosphere of $5 \% \mathrm{CO}_{2}$. Cre recombinase was delivered. Delivery was assessed using confocal microscopy (Nikon A1SP); images were taken at 40x magnification and 'stitched' together using the NIS-Elements software from Nikon. 
(a)

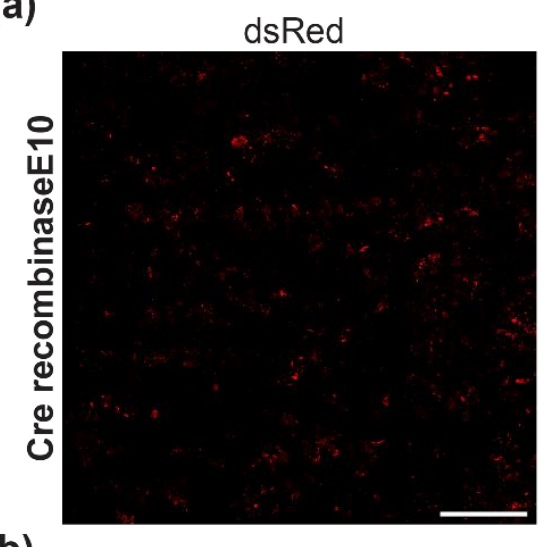

(b)

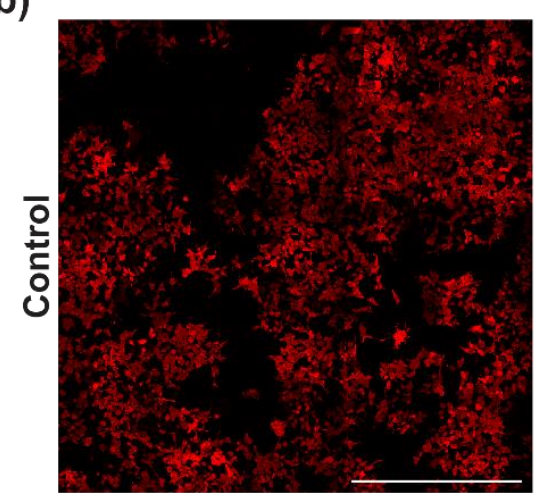

GFP
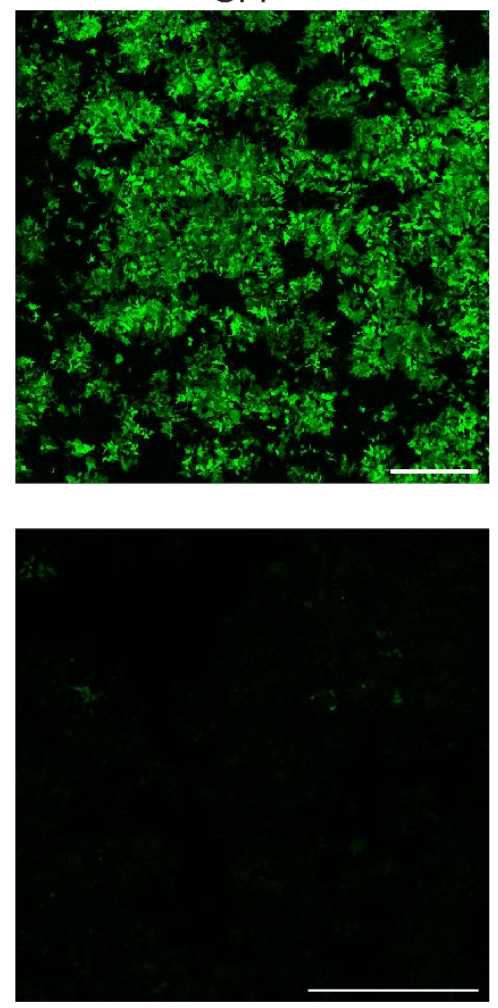

Merged
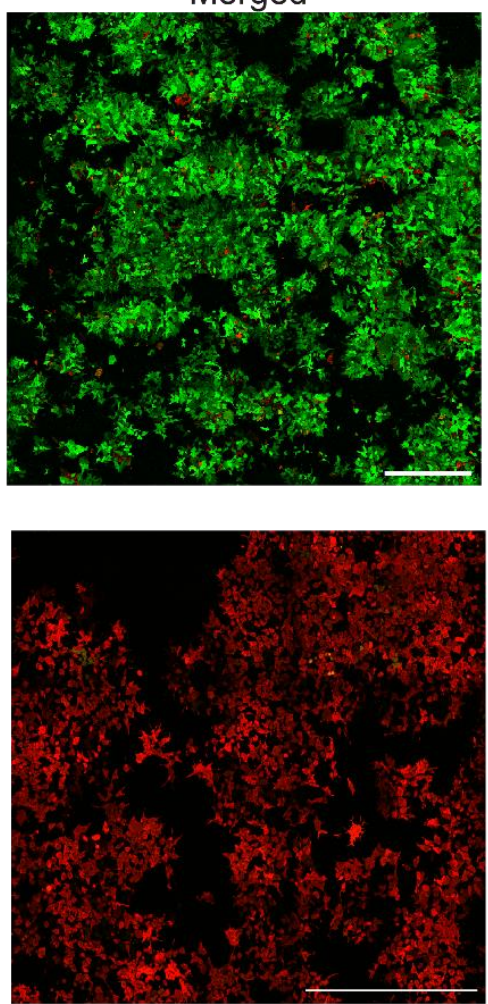

Supplementary Figure S17. Representative confocal large images of HEK-293T reporter cells (a) 10x10 image at 40x magnification after PONI-28k-mediated Cre recombinase E10 delivery (G/E ratio of 10) and (b) control $5 \times 5$ at $40 \times$ magnification. Scale bars $=500 \mu \mathrm{m}$. 


\section{Zeta Potential of PPNC GFPE20 Complexes at Varying Guan/Etag Ratios}

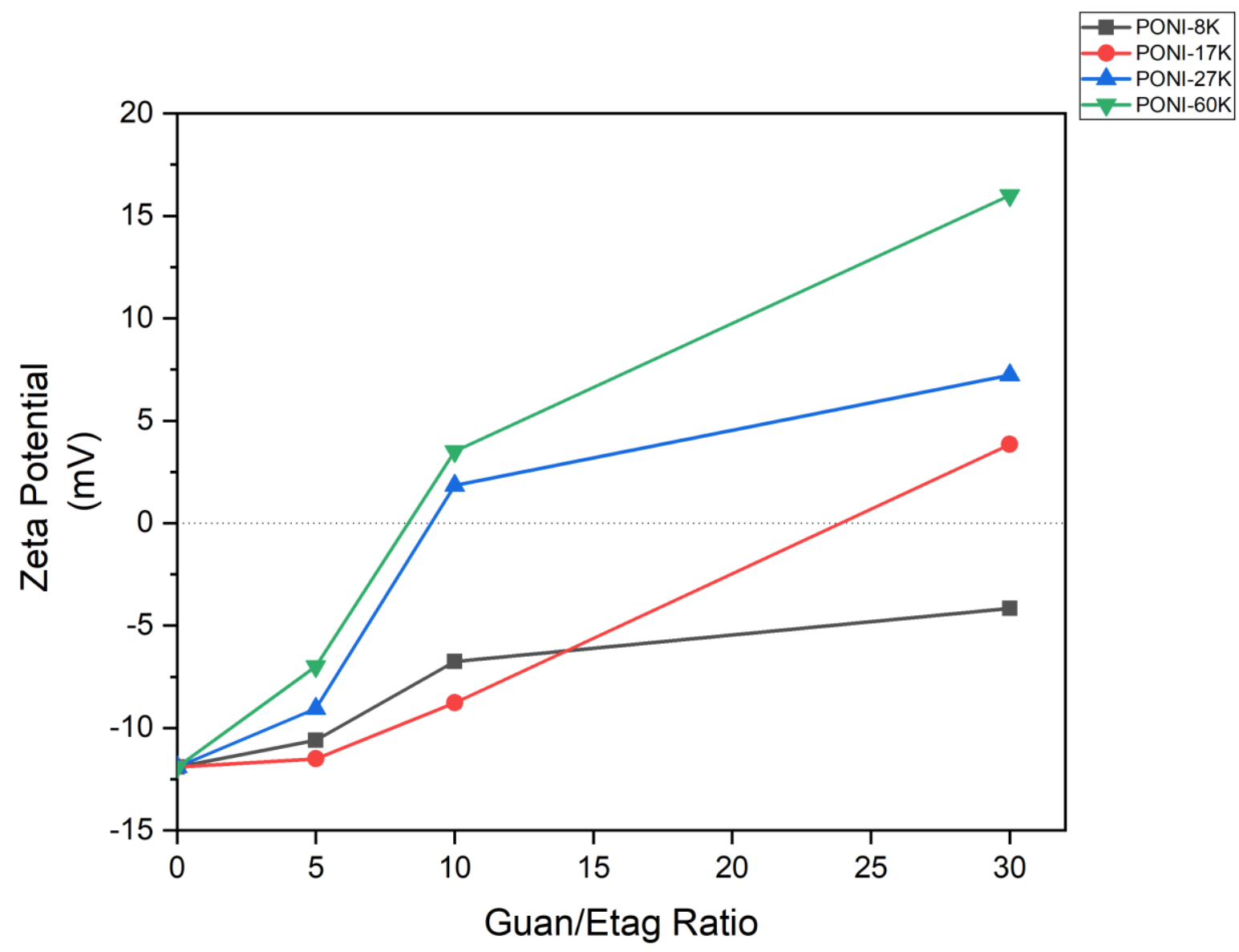

Supplementary Figure S18. Zeta potential of PONI-GFPE20 PPNC complexes at increasing Guan/Etag ratio. PPNCs were measured in PBS (150 mM NaCl, $\mathrm{pH}$ 7.4).

\section{References}

${ }^{1}$ Love, J. A.; Morgan, J. P.; Trnka, T. M.; Grubbs, R. H. A Practical and Highly Active Ruthenium-Based Catalyst That Effects the Cross Metathesis of Acrylonitrile. Angew. Chemie Int. Ed. 2002, 41 (21), 4035 ${ }^{2}$ Landis, R. F.; Gupta, A.; Lee, Y.-W.; Wang, L.-S.; Golba, B.; Couillaud, B.; Ridolfo, R.; Das, R.; Rotello, V. M. Cross-Linked Polymer-Stabilized Nanocomposites for the Treatment of Bacterial Biofilms. ACS Nano 2017, 11 (1), 946-952.

${ }^{3}$ Colak, S.; Tew, G. N. Dual-Functional ROMP-Based Betaines: Effect of Hydrophilicity and Backbone Structure on Nonfouling Properties. Langmuir 2012, 28 (1), 666-675.

${ }^{4}$ Mout, R.; Ray, M.; Yesilbag Tonga, G.; Lee, Y. W.; Tay, T.; Sasaki, K.; Rotello, V. M. Direct cytosolic delivery of CRISPR/Cas9-ribonucleoprotein for efficient gene editing. ACS Nano 2017, 11 (3), 2452. 